\title{
Overexpression of B7-H3 correlates with aggressive clinicopathological characteristics in non-small cell lung cancer
}

\author{
Shanshan Wu ${ }^{1,2, *}$, Xiangfei Zhao ${ }^{2, *}$, Sudong Wu ${ }^{2}$, Rui Du ${ }^{2}$, Qi Zhu ${ }^{2}$, Henghu Fang ${ }^{2}$, \\ Xinhong Zhang ${ }^{2}$, Chunyang Zhang ${ }^{2}$, Wei Zheng', Jihua Yang ${ }^{2}$, Huasong Feng ${ }^{2}$ \\ ${ }^{1}$ Postgraduate Team, Chinese PLA General Hospital, Beijing 100853, China \\ ${ }^{2}$ Department of Radiation Oncology, Navy General Hospital, Beijing 100048, China \\ *These authors have contributed equally to this work
}

Correspondence to: Huasong Feng, email: fenghs99@163.com

Keywords: meta-analysis, B7-H3, prognosis, lung cancer, clinical

Received: September 08, $2016 \quad$ Accepted: October 19, $2016 \quad$ Published: November 07, 2016

\section{ABSTRACT}

Previous studies have investigated the prognostic significance of B7 homolog 3 (B7-H3) in non-small cell lung cancer (NSCLC), however, the results remain controversial. This study was aimed to determine the correlation between B7-H3 and survival as well as clnicalpathological characteristics in NSCLC using metaanalysis. We searched the electronic databases of PubMed, Embase, Web of Science, and China National Knowledge Infrastructure (CNKI) for relevant studies up to October 9, 2016. Pooled hazard ratios (HRs) and 95\% confidence intervals (CIs) were used to estimate the impact of B7-H3 on overall survival (OS). Combined odds ratios (ORs) and $95 \% \mathrm{CIs}$ were utilized to evaluate the correlations between $\mathrm{B} 7-\mathrm{H} 3$ and clinicalpathological features. This meta-analysis finally included 7 studies with 864 patients. The results showed that $\mathrm{B} 7-\mathrm{H} 3$ had no significant association with OS $(\mathrm{HR}=0.88,95 \% \mathrm{CI}: 0.36-2.13, \mathrm{p}=0.776)$. High $\mathrm{B} 7-\mathrm{H} 3$ expression was a significant indicator of lymph node metastasis (OR=3.92, 95\%CI: 2.65-5.81, p<0.001), and advanced TNM stage $(\mathrm{OR}=3.53,95 \% \mathrm{CI}: 2.45-5.09, \mathrm{p}<0.001)$. B7-H3 has the potential to serve as a marker of tumor aggressiveness and lymph node metastasis in NSCLC. However, due to several limitations, further large-scale studies are needed to validate our results.

\section{INTRODUCTION}

Lung cancer is the leading cause of cancer-related deaths worldwide [1]. Lung cancer consists of two main types: small cell lung cancer (SCLC) and nonsmall cell lung cancer (NSCLC). NSCLC accounts for approximately $85 \%$ of all lung cancer cases [2]. In recent decades, major advances have been achieved in surgical techniques, chemotherapy, radiotherapy, and immunotherapy for NSCLC. Unfortunately, treatment outcomes for NSCLC remain poor, with a 5-year survival rate being $15 \%$ [3]. Recent evidence suggests that several mechanisms involving tumor microenvironment results in immune defects in NSCLC, which is responsible for poor prognosis $[4,5]$. Accordingly, there is a need to define immune-related molecular targets and mechanisms to stratify high risk individuals.
B7 homolog $3(\mathrm{~B} 7-\mathrm{H} 3)$ is a member of the coinhibitory B7 family. B7-H3 was first cloned and named in 2001 and was reported to participate in the regulation of $\mathrm{T}$ cell mediated immune responses [6]. $\mathrm{B} 7-\mathrm{H} 3$ is broadly expressed at low levels in normal tissues [7]. Accumulating studies revealed that B7-H3 could inhibit T-cell proliferation, reduce production of cytokines, and suppress activation of transcription factors [8,9]. Recent studies have shown that B7-H3 is upregulated in various malignant tumors including pancreatic cancer [10], prostate cancer [11, 12], renal cell carcinoma [13, 14], and NSCLC [15]. Nevertheless, the clinical significance and prognostic value of B7-H3 in NSCLC are controversial according to present studies [16-19]. In this setting, we searched the relevant studies and conducted this metaanalysis in order to gain a comprehensive understanding of the prognostic impact of B7-H3 on patients with NSCLC. 


\section{RESULTS}

\section{Study selection}

A flow chart describing the study selection process was shown in Figure 1. The initial search strategy identified a total of 94 studies. After duplicates were removed, 75 records were screened on the base of title and abstract. Among them, 20 articles were left for fulltext evaluation. Afterwards, 13 of those 20 articles were discarded due to the following reasons: one was a meeting abstract, one was retracted, five were overlapping studies, and six were without sufficient data. At last, 7 studies [15, 19-24] were included for this meta-analysis.

\section{Study characteristics}

The main characteristics of the 7 eligible studies were listed in Table 1. The studies were published from 2006 to 2016 and six studies were in English $[15,19-21,23,24]$ and one was in Chinese [22]. Six studies were from China [15, 19-23] and one study was from Japan [24]. The sample sizes ranged from 70 to 270 with a sum of 864 . Four studies [19, 21, 23, 24] reported the correlation between $\mathrm{B} 7-\mathrm{H} 3$ and OS and all seven studies showed the association between B7H3 and clinicalpathological features. Six studies [15, 19, 21-24] used immunohistochemistry (IHC) to detect B7-H3 expression and one [20] used enzyme linked immunosorbent assay (ELISA).

\section{B7-H3 expression and overall survival}

A total of 4 studies [19, 21, 23, 24] with 610 patients investigated the impact of $\mathrm{B} 7-\mathrm{H} 3$ on OS. Because of significant heterogeneity $\left(I^{2}=89.9 \%, \mathrm{P}_{\mathrm{h}}<0.001\right)$, a randomeffects model was utilized. The pooled HR and $95 \% \mathrm{CI}$ were: $\mathrm{HR}=0.88,95 \% \mathrm{CI}$ : $0.36-2.13, \mathrm{p}=0.776$; Figure 2 . The results suggested that there was no significant association between B7-H3 expression and OS in NSCLC.

\section{B7-H3 expression and clinicopothological characteristics}

Relevant data were calculated to estimate the correlation between B7-H3 and 8 clinicalpathological parameters. These features included age, gender, lymph node metastasis, tumor differentiation, T stage, histology,

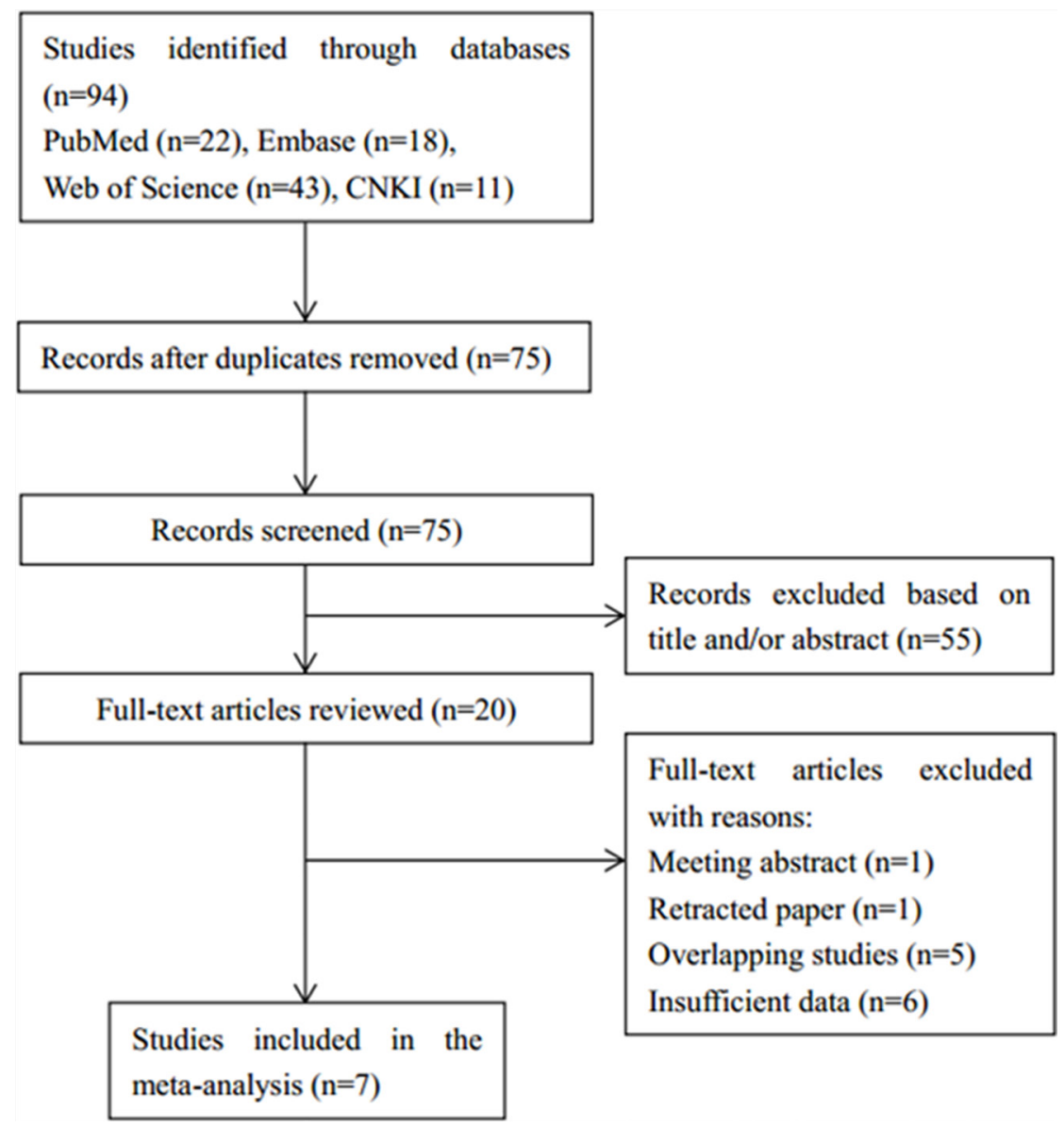

Figure 1: Flow diagram showing selection of studies. 
Table 1: General characteristics of the included studies

\begin{tabular}{|c|c|c|c|c|c|c|c|c|c|c|}
\hline Study & Year & Country & $\begin{array}{c}\text { Sample } \\
\text { size }\end{array}$ & $\begin{array}{c}\text { Gender } \\
(\mathbf{M} / \mathbf{F})\end{array}$ & $\begin{array}{l}\text { TNM } \\
\text { stage }\end{array}$ & Treatment & $\begin{array}{l}\text { Research } \\
\text { duration }\end{array}$ & $\begin{array}{l}\text { Detection } \\
\text { method }\end{array}$ & $\begin{array}{c}\text { Positive } \\
(\%)\end{array}$ & Language \\
\hline Sun & 2006 & China & 70 & $49 / 21$ & I-III & $\begin{array}{l}\text { Surgical } \\
\text { resection }\end{array}$ & $2003-2004$ & $\mathrm{IHC}$ & 37.1 & English \\
\hline Zhang & 2009 & China & 98 & $70 / 28$ & I-IV & $\begin{array}{l}\text { Surgical } \\
\text { resection }\end{array}$ & 2004-2007 & ELISA & 48 & English \\
\hline $\mathrm{Xu}$ & 2010 & China & 102 & $66 / 36$ & I-IV & $\begin{array}{l}\text { Surgical } \\
\text { resection }\end{array}$ & $2006-2008$ & $\mathrm{IHC}$ & 69.6 & English \\
\hline Feng & 2015 & China & 86 & $41 / 45$ & I-IV & $\begin{array}{l}\text { Surgical } \\
\text { resection }\end{array}$ & 2013-2014 & $\mathrm{IHC}$ & 47.7 & Chinese \\
\hline Jin & 2015 & China & 110 & $83 / 27$ & I-III & $\begin{array}{l}\text { Surgical } \\
\text { resection }\end{array}$ & $2006-2015$ & $\mathrm{IHC}$ & 54.55 & English \\
\hline Mao & 2015 & China & 128 & $91 / 37$ & I-III & $\begin{array}{l}\text { Surgical } \\
\text { resection }\end{array}$ & $2005-2007$ & $\mathrm{IHC}$ & 69.5 & English \\
\hline Inamura & 2016 & Japan & 270 & $145 / 125$ & I-IV & $\begin{array}{l}\text { Surgical } \\
\text { resection }\end{array}$ & 1995-2002 & $\mathrm{IHC}$ & 32 & English \\
\hline
\end{tabular}

Abbreviations: $\mathrm{IHC}=$ immunohistochemistry; ELISA= enzyme linked immunosorbent assay.

Study

ID

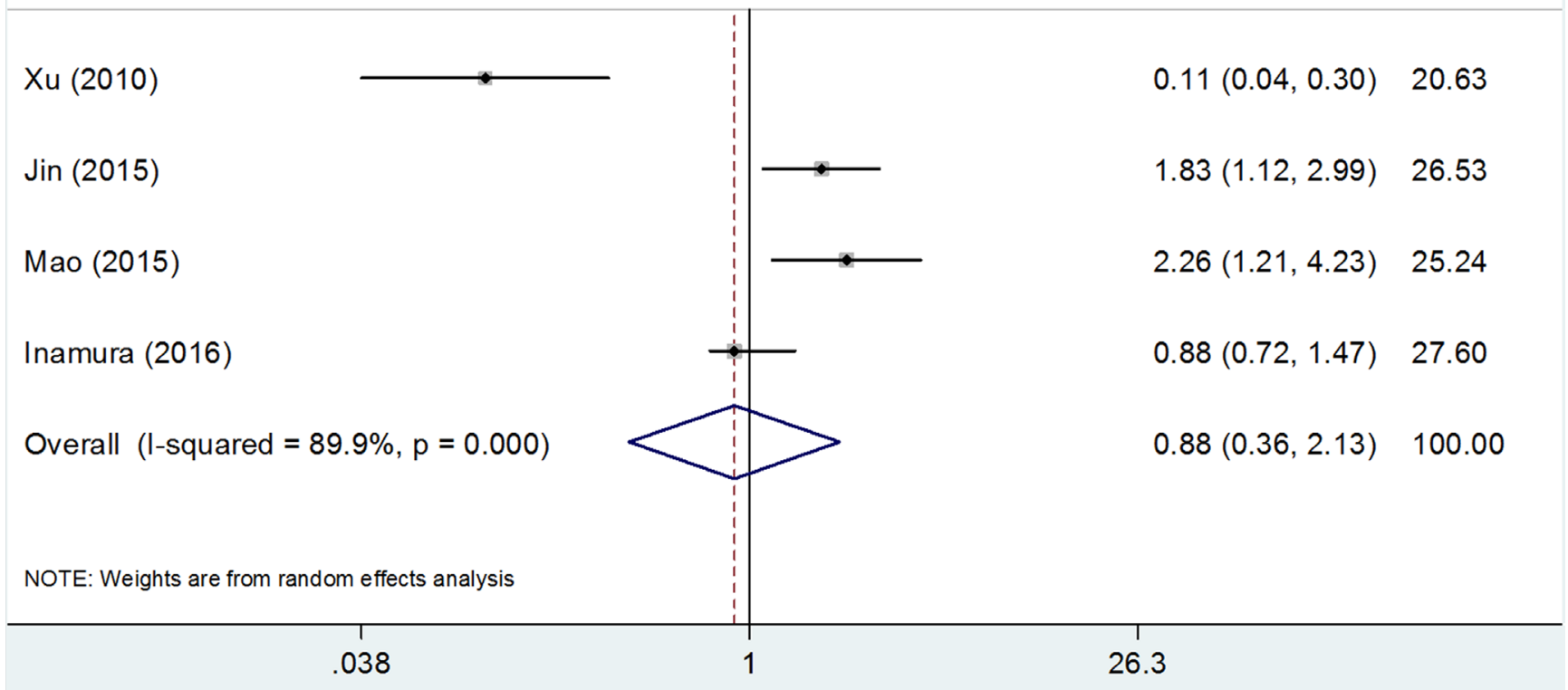

Figure 2: Forest plot depiction of the association between B7-H3 expression and overall survival in NSCLC. 
Table 2: Association between B7-H3 and clinical parameters in NSCLC

\begin{tabular}{|c|c|c|c|c|c|c|}
\hline \multirow{2}{*}{ Parameters } & \multirow{2}{*}{ No. of studies } & \multirow{2}{*}{ Effects model } & \multirow{2}{*}{ OR (95\%CI) } & \multirow{2}{*}{ P-value } & \multicolumn{2}{|c|}{ Heterogeneity } \\
\hline & & & & & $I^{2}(\%)$ & $\mathbf{P}_{\mathrm{h}}$ \\
\hline Age & 7 & Fixed & $1(0.75-1.33)$ & 0.991 & 46.6 & 0.081 \\
\hline Gender & 7 & Random & $1.46(0.93-2.29)$ & 0.099 & 51.4 & 0.055 \\
\hline $\begin{array}{l}\text { Lymph node } \\
\text { metastasis }\end{array}$ & 6 & Fixed & $3.92(2.65-5.81)$ & $<0.001$ & 43.5 & 0.116 \\
\hline Differentiation & 6 & Random & $1.76(0.74-4.15)$ & 0.199 & 79.2 & $<0.001$ \\
\hline T stage & 5 & Random & $1.42(0.73-2.75)$ & 0.303 & 62.1 & 0.032 \\
\hline Histology & 5 & Random & $0.73(0.33-1.61)$ & 0.435 & 76.6 & 0.002 \\
\hline TNM stage & 5 & Fixed & $3.53(2.45-5.09)$ & $<0.001$ & 0 & 0.592 \\
\hline Smoking history & 5 & Fixed & $1.22(0.87-1.71)$ & 0.248 & 0 & 0.88 \\
\hline
\end{tabular}

TNM stage, and smoking history. The overall results were demonstrated in Table 2. The synthesized data showed that there were statistically significant connection between B7-H3 and lymph node metastasis $(\mathrm{OR}=3.92$, 95\% $\mathrm{CI}: 2.65-5.81, \mathrm{p}<0.001)$, and TNM stage $(\mathrm{OR}=3.53$, 95\% $\%$ : 2.45-5.09, $\mathrm{p}<0.001)$. However, the combined data revealed that there was no significant correlation between $\mathrm{B} 7-\mathrm{H} 3$ and age $(\mathrm{OR}=1,95 \% \mathrm{CI}$ : 0.75-1.33, $\mathrm{p}=0.991)$, gender $(\mathrm{OR}=1.46,95 \% \mathrm{CI}: 0.93-2.29, \mathrm{p}=0.099)$, differentiation $(\mathrm{OR}=1.76,95 \% \mathrm{CI}$ : 0.74-4.15, $\mathrm{p}=0.199), \mathrm{T}$ stage $(\mathrm{OR}=1.42,95 \% \mathrm{CI}$ : $0.73-2.75, \mathrm{p}=0.303)$, histology $(\mathrm{OR}=0.73,95 \% \mathrm{CI}: 0.33-1.61, \mathrm{p}=0.435)$, or smoking history $(\mathrm{OR}=1.22,95 \% \mathrm{CI}$ : 0.87-1.71, $\mathrm{p}=0.248)$.

\section{Publication bias}

Potential publication bias statistics were determined by using both Begg's test and Egger's test. As shown in Figure 3, p-values for Begg's test and Egger's test were more than 0.05 (Begg's $p=1$ and Egger's $p=0.634$ for OS). Therefore, no obvious publication bias was detected in our meta-analysis.

\section{DISCUSSION}

NSCLC is one of the most devastating neoplasms around the world. The prognosis of NSCLC was not substantially improved despite therapeutic advancement. Recent progresses in tumor immunology identified a series of costimulatory molecules such as B7 homolog 1 (B7-H1, PD-L1, CD80), B7-H2 (CD 86), B7-H3 (CD 276), and $\mathrm{B} 7-\mathrm{H} 4$ (B7x, B7S1). These costimulatory molecules can combine with their receptors to mediate the intensity of immune responses in physiological and pathological conditions. Immunotherapy targeting B7-H1 has shown promising effects in advanced tumor patients including NSCLC $[25,26]$. These findings encourage us to investigate the prognostic significance of $\mathrm{B} 7-\mathrm{H} 3$ in NSCLC through meta-analysis. In this study, 7 articles with 864 patients were included. The results illustrated that high B7-H3 expression was associated with presence of lymph node metastasis, and advanced TNM stage, whereas B7-H3 had no significant relationship with OS or other clinical characteristics. Our results suggested that B7-H3 was a potential stimulator for tumor cells dissemination and invasion. To the best of our knowledge, this is the first comprehensive meta-analysis to assess the prognostic role of B7-H3 in patients with NSCLC.

$\mathrm{B} 7-\mathrm{H} 3$ is a type I transmembrane protein which shares $\sim 25 \%$ amino acid identity with B7-H1 and B7$\mathrm{H} 2$ [6]. B7-H3 protein is widely expressed in peripheral tissues including osteoblasts, fibroblasts, human liver, bladder, placenta, and lymphoid organs [27]. Growing evidence showed that B7-H3 was implicated in inhibiting $\mathrm{T}$ cells-mediated immune reactions [28]. Furthermore, the interaction between CD4+CD25+ regulatory T cells (Tregs) and dendritic cells (DCs) induces expression of B7-H3 on DCs [29]. A number of studies demonstrated the prognostic effect of B7-H3 on different solid tumors. Yamato et al [10] reported that B7-H3 expression was significantly more intense in cases with lymph node metastasis and advanced pathological stage in pancreatic cancer. Yuan et al [30] found that B7-H3 overexpression could promote tumor cells migration and invasion in prostate cancer. Qin et al [14] showed that B7-H3 expression was associated with multiple adverse clinical and pathologic features in renal cell carcinoma. Moreover, Huang et al [31] revealed that B7-H3 levels were significantly associated with tumor size in patients with cervical cancer. Wang et al [32] disclosed that high B7-H3 expression was an indicator of advanced stage and common pulmonary metastasis 
in osteosarcoma. In the current meta-analysis, we found that B7-H3 overexpression was correlated with lymph node metastasis, and advanced TNM stage, which were in accordance with previous findings [10, 14, 31, 32]. Notably, some studies [12, 32] showed that patients with high tumor B7-H3 levels had shorter survival time and recurrence time. Interestingly, the data in our study did not suggest that B7-H3 expression predict poor survival in NSCLC. The reason may be that the total sample size in this meta-analysis is limited, which may introduce bias.

Despite its strengths, this meta-analysis still has several limitations. First, all primary studies included were from Asia, which may cause selection bias. Although many studies from other countries were searched, they were removed because they did not meet inclusion criteria. Second, the sample size was relatively small in this metaanalysis. More studies are especially needed to explore the relationship between B7-H3 and OS.

In conclusion, this meta-analysis illustrated that B7-H3 was significantly associated with lymph node metastasis, and advanced TNM stage in NSCLC. However, B7-H3 had no significant connection with OS in NSCLC. B7-H3 has the potential to serve as a marker of tumor aggressiveness and metastasis. Due to the limitations, further large-scale studies from different countries are warranted.

\section{MATERIALS AND METHODS}

\section{Search strategy}

This meta-analysis was performed referring to Preferred Reporting Items for Systematic Reviews and Meta-Analyses (PRISMA) guidelines [33]. Relevant studies were searched through the electronic platforms of
PubMed, Embase, Web of Science, and China National Knowledge Infrastructure (CNKI) up to October 9, 2016. Search items included "B7-H3", "B7H3", "B7 homolog 3", “CD276", "lung cancer", "lung carcinoma", "nonsmall cell lung cancer", and "NSCLC". The reference lists were also manually searched to identify potentially related articles.

\section{Inclusion and exclusion criteria}

Eligible studies were required to meet the following criteria: (1) the diagnosis of NSCLC was proven by pathological methods; (2) studies investigated the relationships between $\mathrm{B} 7-\mathrm{H} 3$ and overall survival (OS) or clinicopathological characteristics; (3) B7-H3 expression was measured by any method; (4) hazard ratio (HR) and $95 \%$ confidence interval (CI) of OS or odds ratio (OR) and $95 \% \mathrm{CI}$ of clinicopathological characteristics were reported or could be calculated by Tierney's method [34]; (5) studies were published as full-text articles in English or Chinese; (6) if the same patient group was reported more than once, the most complete one was included. Animal studies, duplicate articles, abstracts and studies with insufficient information were removed from the analysis.

\section{Data extraction}

All data were extracted by two independent investigators (SSW and XFZ) from eligible studies. Any disagreement between the two investigators was settled by discussion. The following information was extracted: first author, year of publication, study location, age, gender, sample size, TNM stage, treatment strategies, detection method for $\mathrm{B} 7-\mathrm{H} 3$, research duration, and publication language.
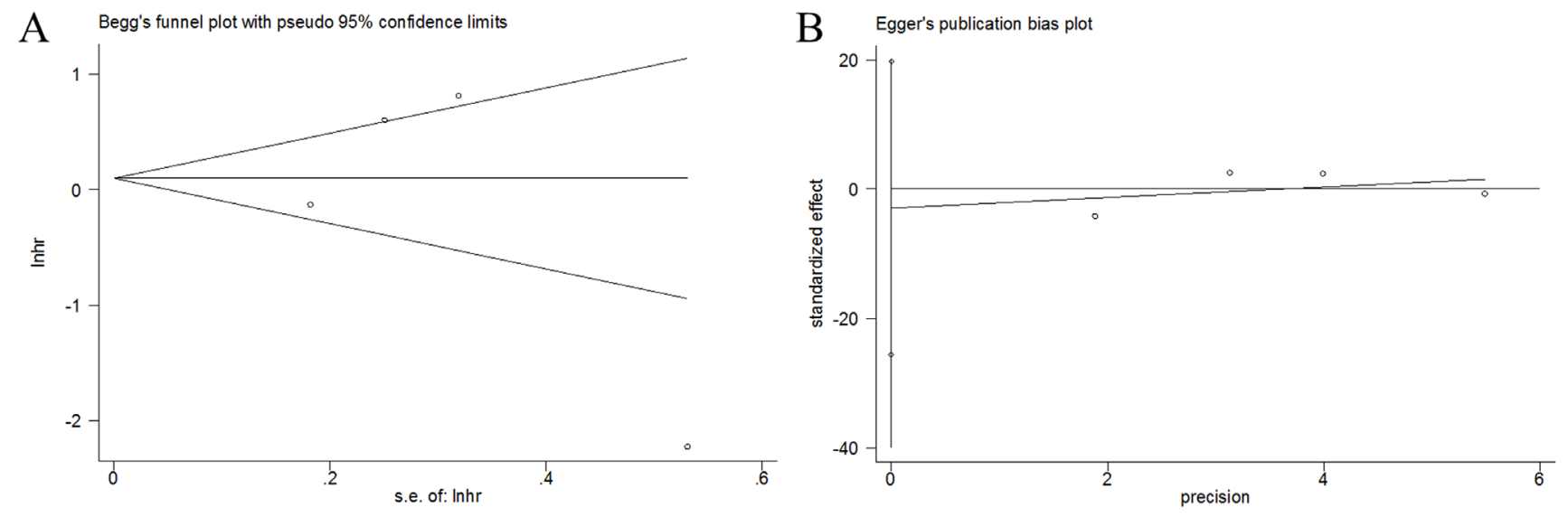

Figure 3: Publication bias detected by Begg's test and Egger's test. A. Begg's test for OS. B. Egger's test for OS. 


\section{Statistical analysis}

HR with $95 \% \mathrm{CI}$ was used to strength of association between B7-H3 and OS. Heterogeneity among studies was evaluated by using chi-square based Q-test [35] and Higgins $I^{2}$ statistic [36]. Significant heterogeneity was defined as $\mathrm{p}$ for heterogeneity $<0.10$ or $I^{2}>50 \%$. If significant heterogeneity was found, a random-effects model was performed for analysis, otherwise, a fixedeffects model was applied. ORs and 95\%CIs were utilized as the effect sizes to assess the association between B7$\mathrm{H} 3$ and clinical parameters in NSCLC. Publication bias in meta-analysis was estimated using Begg's funnel plot and Egger's linear regression tests. $\mathrm{P}<0.05$ was considered as statistically significant. All statistical analyses were accomplished using the STATA 12.0 software (Stata corp, College station, TX).

\section{CONFLICTS OF INTEREST}

The authors confirm that there are no conflicts of interest.

\section{REFERENCES}

1. Torre LA, Bray F, Siegel RL, Ferlay J, Lortet-Tieulent J, Jemal A. Global Cancer Statistics, 2012. CA-Cancer J Clin. 2015; 65:87-108.

2. Molina JR, Yang P, Cassivi SD, Schild SE, Adjei AA. Nonsmall cell lung cancer: epidemiology, risk factors, treatment, and survivorship. Mayo Clin Proc. 2008; 83:584-594.

3. Alberg AJ, Ford JG, Samet JM. Epidemiology of lung cancer: ACCP evidence-based clinical practice guidelines (2nd edition). Chest. 2007; 132:29s-55s.

4. Grivennikov SI, Greten FR, Karin M. Immunity, Inflammation, and Cancer. Cell. 2010; 140:883-899.

5. Hanahan D, Weinberg RA. Hallmarks of cancer: the next generation. Cell. 2011; 144:646-674.

6. Chapoval AI, Ni J, Lau JS, Wilcox RA, Flies DB, Liu D, Dong HD, Sica GL, Zhu GF, Tamada K, Chen LP. B7-H3: A costimulatory molecule for $\mathrm{T}$ cell activation and IFNgamma production. Nat Immunol. 2001; 2:269-274.

7. Sun M, Richards S, Prasad DV, Mai XM, Rudensky A, Dong C. Characterization of mouse and human B7-H3 genes. J Immunol. 2002; 168:6294-6297.

8. Ling V, Wu PW, Spaulding V, Kieleczawa J, Luxenberg D, Carreno BM, Collins M. Duplication of primate and rodent B7-H3 immunoglobulin V- and C-like domains: divergent history of functional redundancy and exon loss. Genomics. 2003; 82:365-377.

9. Prasad DVR, Nguyen T, Li ZX, Yang Y, Duong J, Wang Y, Dong C. Murine B7-H3 is a negative regulator of T cells. Journal of Immunology. 2004; 173:2500-2506.
10. Yamato I, Sho M, Nomi T, Akahori T, Shimada K, Hotta K, Kanehiro H, Konishi N, Yagita H, Nakajima Y. Clinical importance of B7-H3 expression in human pancreatic cancer. Br J Cancer. 2009; 101:1709-1716.

11. Roth TJ, Sheinin Y, Lohse CM, Kuntz SM, Frigola X, Inman BA, Krambeck AE, McKenney ME, Karnes RJ, Blute NL, Cheville JC, Sebo TJ, Kwon ED. B7-H3 ligand expression by prostate cancer: A novel marker of prognosis and potential target for therapy. Cancer research. 2007; 67:7893-7900.

12. Zang X, Thompson RH, Al-Ahmadie HA, Serio AM, Reuter VE, Eastham JA, Scardino PT, Sharma P, Allison JP. B7-H3 and $\mathrm{B} 7 \mathrm{x}$ are highly expressed in human prostate cancer and associated with disease spread and poor outcome. Proc Natl Acad Sci U S A. 2007; 104:19458-19463.

13. Crispen PL, Sheinin Y, Roth TJ, Lohse CM, Kuntz SM, Frigola X, Thompson RH, Boorjian SA, Dong H, Leibovich BC, Blute ML, Kwon ED. Tumor cell and tumor vasculature expression of B7-H3 predict survival in clear cell renal cell carcinoma. Clin Cancer Res. 2008; 14:5150-5157.

14. Qin XJ, Zhang HL, Ye DW, Dai B, Zhu Y, Shi GH. B7-H3 is a new cancer-specific endothelial marker in clear cell renal cell carcinoma. OncoTargets and therapy. 2013; 6:1667-1673.

15. Sun Y, Wang Y, Zhao J, Gu M, Giscombe R, Lefvert AK, Wang X. B7-H3 and B7-H4 expression in non-small-cell lung cancer. Lung Cancer. 2006; 53:143-151.

16. Schneider T, Hoffmann H, Dienemann H, Schnabel PA, Enk AH, Ring S, Mahnke K. Non-small cell lung cancer induces an immunosuppressive phenotype of dendritic cells in tumor microenvironment by upregulating B7-H3. Journal of thoracic oncology. 2011; 6:1162-1168.

17. Boland JM, Kwon ED, Harrington SM, Wampfler JA, Tang H, Yang P, Aubry MC. Tumor B7-H1 and B7-H3 expression in squamous cell carcinoma of the lung. Clinical lung cancer. 2013; 14:157-163.

18. Kawabata R, Nishiyama M. RNA-sequencing data analysis suggests that immunotherapy might be a potent treatment option in elderly non-small cell lung cancer patients. Annals of Oncology. 2015; 26:ix12.

19. Jin Y, Zhang P, Li J, Zhao J, Liu C, Yang F, Yang D, Gao A, Lin W, Ma X, Sun Y. B7-H3 in combination with regulatory $\mathrm{T}$ cell is associated with tumor progression in primary human non-small cell lung cancer. International journal of clinical and experimental pathology. 2015; 8:13987-13995.

20. Zhang G, Xu Y, Lu X, Huang H, Zhou Y, Lu B, Zhang X. Diagnosis value of serum B7-H3 expression in non-small cell lung cancer. Lung Cancer. 2009; 66:245-249.

21. Xu YH, Zhang GB, Wang JM, Hu HC. B7-H3 and CD133 expression in non-small cell lung cancer and correlation with clinicopathologic factors and prognosis. Saudi Med J. 2010; 31:980-986. 
22. Feng W, Yu Q, Zhang B, Zhang JB, Zhang MM. Expression and significance of $\mathrm{CO}$ signaling molecule B7-H3 in human lung adenocarcinoma. Guangdong Medical Journal 2015; 1869-1871.

23. Mao YX, Li W, Chen K, Xie YF, Liu Q, Yao M, Duan WM, Zhou XM, Liang RR, Tao M. B7-H1 and B7-H3 are independent predictors of poor prognosis in patients with non-small cell lung cancer. Oncotarget. 2015; 6:3452-3461. doi: 10.18632/oncotarget.3097.

24. Inamura K, Yokouchi Y, Kobayashi M, Sakakibara R, Ninomiya H, Subat S, Nagano H, Nomura K, Okumura S, Shibutani T, Ishikawa Y. Tumor B7-H3 (CD276) expression and smoking history in relation to lung adenocarcinoma prognosis. Lung Cancer. 2016; 243:21-28.

25. Herbst RS, Soria JC, Kowanetz M, Fine GD, Hamid O, Gordon MS, Sosman JA, McDermott DF, Powderly JD, Gettinger SN, Kohrt HEK, Horn L, Lawrence DP, Rost S, Leabman M, Xiao YY, et al. Predictive correlates of response to the anti-PD-L1 antibody MPDL3280A in cancer patients. Nature. 2014; 515:563-+.

26. Brahmer JR, Tykodi SS, Chow LQM, Hwu WJ, Topalian SL, Hwu P, Drake CG, Camacho LH, Kauh J, Odunsi K, Pitot HC, Hamid O, Bhatia S, Martins R, Eaton K, Chen SM, et al. Safety and Activity of Anti-PD-L1 Antibody in Patients with Advanced Cancer. N Engl J Med. 2012; 366:2455-2465.

27. Loos M, Hedderich DM, Friess H, Kleeff J. B7-H3 and Its Role in Antitumor Immunity. Clinical \& Developmental Immunology. 2010.

28. Fukushima A, Sumi T, Fukuda K, Kumagai N, Nishida T, Yamazaki T, Akiba H, Okumura K, Yagita H, Ueno H. B7-H3 regulates the development of experimental allergic conjunctivitis in mice. Immunology letters. 2007; 113:52-57.

29. Mahnke K, Ring S, Johnson TS, Schallenberg S, Schonfeld K, Storn V, Bedke T, Enk AH. Induction of immunosuppressive functions of dendritic cells in vivo by $\mathrm{CD} 4+\mathrm{CD} 25+$ regulatory $\mathrm{T}$ cells: role of $\mathrm{B} 7-\mathrm{H} 3$ expression and antigen presentation. Eur J Immunol. 2007; 37:2117-2126.

30. Yuan HX, Wei XD, Zhang GB, Li C, Zhang XG, Hou JQ. B7-H3 Over Expression in Prostate Cancer Promotes Tumor Cell Progression. Journal of Urology. 2011; 186:1093-1099.

31. Huang CL, Zhou L, Chang XH, Pang XA, Zhang HJ, Zhang SL. B7-H3, B7-H4, Foxp3 and IL-2 expression in cervical cancer: Associations with patient outcome and clinical significance. Oncol Rep. 2016; 35:2183-2190.

32. Wang L, Zhang Q, Chen W, Shan BE, Ding Y, Zhang GC, Cao NN, Liu L, Zhang YZ. B7-H3 is Overexpressed in Patients Suffering Osteosarcoma and Associated with Tumor Aggressiveness and Metastasis. PloS one. 2013; 8.

33. Moher D, Liberati A, Tetzlaff J, Altman DG. Preferred reporting items for systematic reviews and meta-analyses: the PRISMA statement. PLoS medicine. 2009; 6:e1000097.

34. Tierney JF, Stewart LA, Ghersi D, Burdett S, Sydes MR. Practical methods for incorporating summary time-to-event data into meta-analysis. Trials. 2007; 8:16.

35. Cochran WG. The combination of estimates from different experiments. Biometrics. 1954; 10:101-129.

36. Higgins JPT, Thompson SG. Quantifying heterogeneity in a meta-analysis. Stat Med. 2002; 21:1539-1558. 